\title{
掌および手での接触抵抗に関する評価方法の提示
}

動作支援，姿勢保持からみた建築部位・部材の接触抵抗の評価方法に関する研究

\section{ESTABLISHMENT OF MEASUREMENT METHOD OF CONTACT RESISTANCE \\ WITH PALMS AND HANDS}

Study on evaluation method of contact resistance of building elements and members from the view point of motion support and posture control

\section{新美 浩二*1, 工藤 瑠 美*2, 古賀 (井戸川) 純子*3, 細 界 守明*4, 横 山 裕*5 \\ Koji NIIMI, Rumi KUDOU, Junko KOGA, Moriaki HOSOKAI and Yutaka YOKOYAMA}

\begin{abstract}
The purpose of this study is to present the evaluation method of contact resistance of building elements and members with palms and hands from the view point of motion support and posture control. First, sensory tests to make evaluation scales from the view point of motion support and posture control with palms and hands were carried out. Next, the contact resistance meter with palms and hands that could measure the contact resistance of samples were developed. Then, coefficients of contact resistance of the samples were searched with the contact resistance meter. Also, the relations were investigated between contact resistance and evaluation scales from the view point of motion support and posture control. As a result, the measurement method of contact resistance of building elements and members with palms and hands were presented.
\end{abstract}

\section{Keywords : motion support, posture control, contact resistance, building elements and members, palms, hands 動作支援，姿勢保持，接触抵抗，建築部位・部材，掌，手}

1. 序

人は、歩行、立つ、座るなどの動作をしたり、立位などの姿勢を 保つ際、身体の一部を壁や机などの建築部位・部材や什器・備品な ど(以降、単に部位·部材と記す)に接触させることにより、動作をし やすくしたり、姿勢を安定させたりできることが経験的に認識され ている。このような部位・部材に触れることによる動作支援、姿勢保 持は、身体能力の低下がみられる高齢者や身体に障害をもった人々 はもとより、健常者でもしばしば観察される行為であることから、 幅広い層の人々の日常生活を安全、円滑にする上で重要と思われる。 部位·部材に触れることによる動作支援、姿勢保持には、身体と部 位·部材との相対的なずれの生じにくさ、すなわち接触抵抗が大きく 影響することは、容易に予測できる。本研究は、身体部位のうち、 最も自然に使われ、頻度も高く、かつ効果も大きいと思われる手で 触れる場合を対象に、部位・部材との接触抵抗を評価する方法を確立 することを、最終的な目的としている。

部位・部材に手で触れる場合について観察すると、まず始めに指が
触れ、さらに場合によっては掌(てのひら)まで触れる。また、頻度

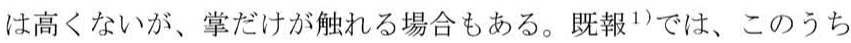
最も頻度の高い『指』で部位・部材に触れる場合の接触抵抗の評価方 法を提示した。本報では、『掌』が触れる場合と、さらに指と掌を合 わせた『手』全体が触れる場合の評価方法を提示した経緯、結果を 述べる。

\section{2. 目的と範囲}

本報は、動作支援、姿勢保持の観点から、掌と部位・部材の接触抵 抗を評価する方法を提示し、さらに既報の結果と合わせて、指と掌 全体 (以降、単に手と記す) と部位・部材の接触抵抗を評価する方法を 提示することを目的とする。

本報では、部位・部材に触れる場合を対象とし、部位・部材をつか んだり握ったりする場合は範囲外とする。

対象とする部位・部材の形状は、掌または手で触れられる大きさ をもつ平らな面とする。

\footnotetext{
*1 (侏) INAX 総合技術研究所 東京工業大学 博士後期課程(社会人大学院プログラム)・修士(心理学)

*2 奈良女子大学生活環境学部 助教・博士 (工学)

*3 独立行政法人建築研究所 主任研究員·博士 (工学)

$* 4$ 東北測器株) 代表取締役

*5 東京工業大学大学院理工学研究科建築学専攻 准教授·工博
}

General Research Institute of Technology, INAX Corporation Graduate School, Tokyo Institute of Technology, M. Psy.

Assistant Prof., Faculty of Human Life and Environment, Nara Women's University, Dr. Eng. Senior Researcher, Building Research Institute, Dr. Eng.

President, Touhoku Sokki Corp.

Assoc. Prof., Dept. of Architecture and Building Eng., Graduate School of Science and Eng., Tokyo Institute of Technology, Dr. Eng. 
また、部位・部材表面の断面形状の観点からは、平滑なものだけで なく、テクスチャーとみなせる深さ $1 \mathrm{~mm}$ 程度の凹凸を有するものま でを対象とすることとし、それより大きな凹凸を有する表面は、接 触時の痛さや怪我のしやすさ、さらには清掃性の観点から実用性に そしいと思われることから、範囲外とする。

\section{3. 既往の研究}

手と部位・部材との接触抵抗に関連する既往の研究としては、筆者 らの既報 ${ }^{1)}$ 以外に、井戸川、小野 2) 4) の研究があげられる。この 研究では、手すりを握る場合や、壁、床に手をつく場合を対象に、 手と部位・部材のすべりを測定できる妥当な試験機を開発するとと もに、開発した試験機を軸とした安全性からみたすべりの評価方法 を提示している。この研究は、手と部位·部材のすべりの妥当な評価 方法を国内外で初めて提示した研究として貴重な成果といえる。こ の研究の試験機は、ゴムチューブを系で縛って固定したすべり片を 手すりや壁、床に接触させ、すべり片に重鍾の質量を載荷した状態 で所定の方向に引張る構造となっている。ここで、ゴムチューブを 系で縛って固定したすべり片としたのは、当初手すりを握る場合を 対象とした試験機であり、指の形状を立体的に模擬することを意図 したことによるものである。しかし、この試験機では、系を縛る強 さのわずかな差によるすべり片の形状の微妙な変化が結果に反映さ れるため、再現性にやや難がある。この点は、試験機の根本的な構 成による問題であり、この試験機を基本に考える限り解決困難な問 題と考える。一方、既報では、指での接触抵抗を接触面が平らな形 状の接触抵抗片を用いて測定し、安定した結果を得ている。

以上より、本報では、井戸川、小野2) 4) の開発した試験機を適 用することはせず、既報の試験機を適宜改造して用いることにより、 評価方法を提示することとした。

\section{4. 研究方法}

本報における研究方法および手順は、次のとおりである。

(1) 官能検查手法を用いて、掌を接触させることによる動作支援、姿 勢保持のしやすさ、しにくさに関する心理学的尺度を構成する。 また、構成した尺度相互の関係を検討する。

(2) (1)での検討結果を参考に、掌での接触抵抗を測定できる試験機を 設計・試作する。

(3) (2)で設計·試作した試験機による測定結果と(1)で構成した心理学 的尺度との関係を検討し、動作支援、姿勢保持からみた建築部 位・部材の掌での接触抵抗の評価方法を提示する。

(4) (1) と同様に、官能検查手法を用いて、手を接触させた場合の心理 学的尺度を構成する。また、構成した尺度相互の関係を検討する。

(5) (4)での検討結果と、既報 ${ }^{1)}$ で設計・試作した指での接触抵抗を測 定できる試験機および(2)で設計·試作した掌での接触抵抗を測定 できる試験機を参考に、手での接触抵抗を測定できる試験機を設 計・試作する。

(6) (5)で設計・試作した試験機による測定結果と(4)で構成した心理学 的尺度との関係を検討し、動作支援、姿勢保持からみた建築部 位・部材の手での接触抵抗の評価方法を提示する。

\section{5. 掌を接触させる場合の心理学的尺度の構成}

\section{1 官能検査の概要}

心理学的尺度構成のため、以下に示寸要領で官能検查を行った。 官能検査の概要は、表 1 のとおりである。

\section{1.1 構成する尺度および尺度構成手法}

構成する尺度は、検査試料に掌を触れながら動作した時にどの程 度動作しやすいかを表す動作支援尺度 (以降、支援尺度と記す)、お よび検査試料に掌を触れながら姿勢を保った時にどの程度姿勢保持 しやすいかを表す姿勢保持尺度（以降、保持尺度と記す）とした。 尺度構成手法は、系列範ちゅう法 ${ }^{5}$ ) とし、表 1 に示す 5 段階の判 断範ちゅうを用いて検查を行った。

\section{1 .2 検査試料の概要}

検查試料として、表 1 に示すとおり、材質、表面形状が異なる板 状ないしシート状材料と、これらの材料の表面状態の組合せ $7 \sim 10$ 種を設定した。検查試料の設定にあたっては、掌で触れた時の接触 抵抗が多様になること、検查員に疲労、倦总を感じさせない検査試 料数とすることに留意した。検査試料の大きさは、 $450 \times 300 \mathrm{~mm}$ とし た。

表 1 心理学的尺度構成のための官能検查の概要

\begin{tabular}{|c|c|c|}
\hline $\begin{array}{l}\text { 構成する尺度 } \\
※(\text { )内は略称 }\end{array}$ & 動作支援尺度 (支援尺度) & 姿勢保持尺度 (保持尺度) \\
\hline 尺度構成手法 & \multicolumn{2}{|l|}{ 系列範ちゅう法 } \\
\hline 質問事項 & \multicolumn{2}{|c|}{ 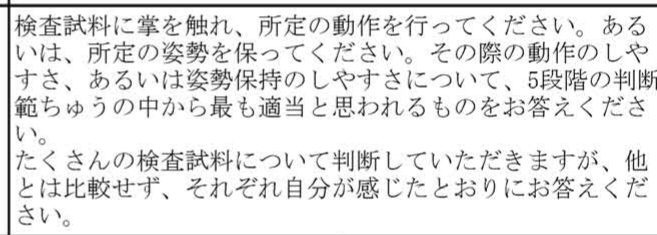 } \\
\hline 判断範ちゅう & $\begin{array}{l}\text { (1)かなり動作しにくい } \\
\text { (2)ややや動作しにくい } \\
\text { (3)どちらでもない } \\
\text { (4)やや動作しやすい } \\
\text { (5)かなり動作しやすい }\end{array}$ & 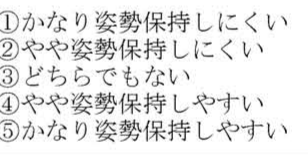 \\
\hline \multirow{3}{*}{$\begin{array}{l}\text { 動作および姿勢 } \\
※(\text { ( )内は略称 }\end{array}$} & $\begin{array}{c}\text { 椅子から立ち上がる } \\
\text { (椅子立ち) }\end{array}$ & \multirow{3}{*}{$\begin{array}{l}\text { 片足で立つ } \\
\text { (片足立ち) }\end{array}$} \\
\hline & $\begin{array}{l}\text { 椅子に座る } \\
\text { (椅子座り) }\end{array}$ & \\
\hline & $\begin{array}{l}\text { 踄< } \\
\text { (歩行) }\end{array}$ & \\
\hline 接触面の向き & \multicolumn{2}{|l|}{ 水平、鉛直 (写真 1 参照) の2 種 } \\
\hline 検査試料 & \multicolumn{2}{|c|}{ 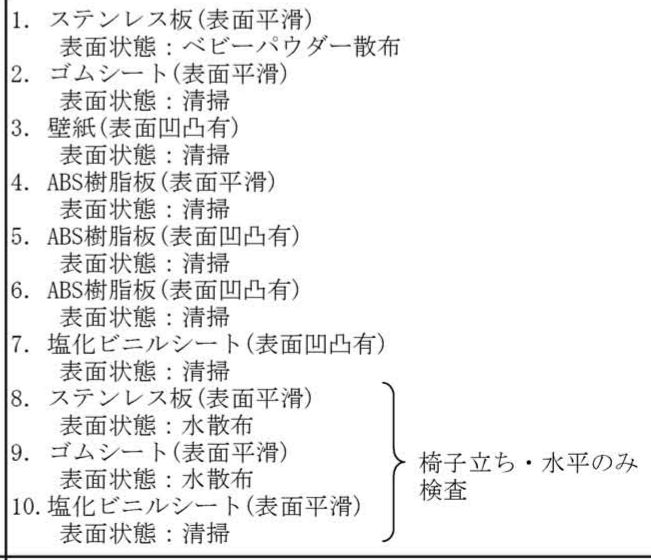 } \\
\hline 検査員 & \multicolumn{2}{|c|}{ 23〜48歳の健常者14名 (男子8名、女子6名) } \\
\hline
\end{tabular}




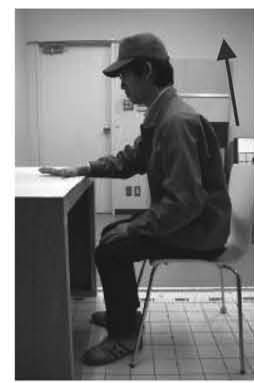

動作 : 椅子立ち 試料面の向き：水平

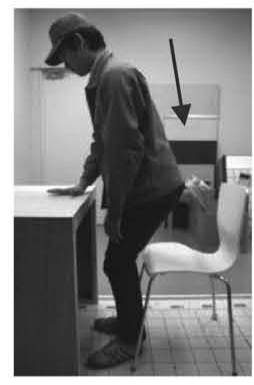

動作 : 椅子座り 試料面の向き：水平

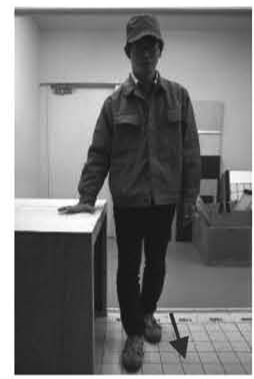

動作 : 歩行 試料面の向き：水平

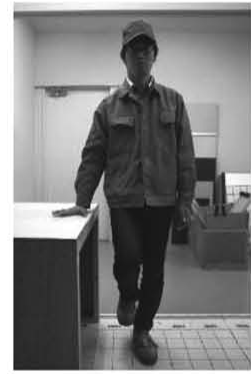

動作：片足立ち 試料面の向き：水平

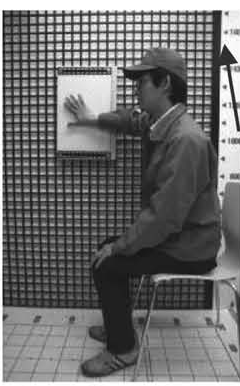

動作 : 椅子立ち 試料面の向き：鉛直

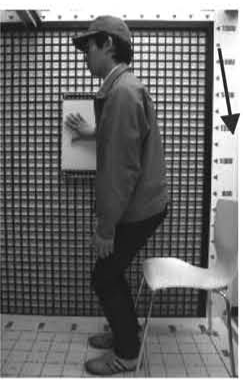

動作 : 椅子座り

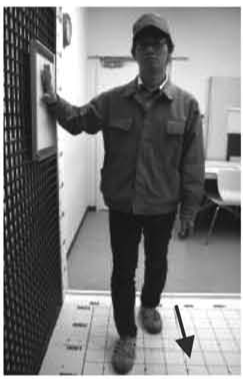

動作 : 歩行 試料面の向き：鉛直

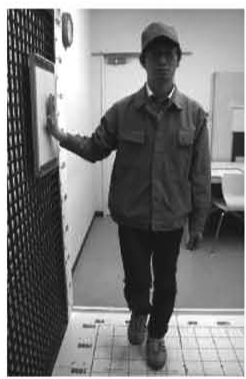

動作：片足立ち 試料面の向き：鉛直 試料面の向き：鉛直

写真 1 官能検查状況

\section{1.3 動作、姿勢}

動作のしやすさに関する検查では、日常頻繁に行われ、かつ部位・ 部材に身体部位を触れることにより容易になる動作の中から、代表 的なものとして、椅子立ち、椅子座り、歩行の 3 種を選定した。

一方、姿勢保持のしやすさに関する検査では、種々想定される不 安定な姿勢の中から、代表的なものとして、片足立ちを選定した。

検査の際、検査員は、あらかじめ検査試料に掌を触れ、その状態 から所定の動作をおこなう、あるいは所定の姿勢を保つこととした。

\section{1.4 試料面の向き}

掌を触れる面の向きは、水平と鉛直の 2 種とした。具体的には、 写真 1 に示すように、椅子立ち・水平、椅子座り・水平では身体の 正面で試料面に触れることとし、椅子立ち・鉛直、椅子座り・鉛直 では身体の側面で試料面に触れることとした。また、歩行、片足立 ちでは、水平、鈶直ともに身体の側面で試料面に触れることとした。 なお、鉛直の場合は、いずれも試料面が検查員の身体の前後方向と 平行になるよう設定した。試料面の高さや検查員との距離は、自然 な動作、姿勢となるよう検查員の体格に応じて調整した。

\section{1.5 検査員}

検查員は、23〜48 歳の健常者 14 名 (男子 8 名、女子 6 名) とした。 本来は、高齢者や身体に障害をもった人も検査員とすることが望ま しいが、身体的負担が大きいこと、動作時に転倒など大きな危険が 伴うことから、健常者のみとした。なお、本報で対象とする部位・ 部材を触れることによる動作支援および姿勢保持は健常者でも日常 生活の中で観察される行為であることから、健常者を対象とした評 価方法を提示すること自体にも十分価值があると考える。一方、上 述の理由から、高齢者や身体に障害をもった人を対象とした評価を 検查を通じて直接得ることは困難と思われるが、床のすべりを対象 とした小野ら $5^{5}$ の研究成果などから、接触抵抗の評価の相対的判断 は健常者と大きくは異ならないと予想できる。よって、本研究では、 健常者での尺度を、高齢者、身体に障害をもつた人々の評価を類推 できる現実的に可能な範囲内で最も有効な資料と位置付けることと した。

\section{2 官能検査の経過、結果および心理学的尺度の構成}

5.1 で述べた条件で、官能検查を実施した。検查室の温度は $25^{\circ} \mathrm{C}$ $\pm 3^{\circ} \mathrm{C}$ 、湿度は $60 \pm 5 \%$ とした。1 人の検査員の検査に要する時間は 約 1 時間で、検查員の疲労も考慮し、休毠を入れつつ検查を実施し た。検査試料の提示順序は、検查結果に与える影響に配慮し、検査 員ごとに無作為とした。また、室温および湿度の変動による掌の発 汗の違いが判断に及ぼす影響をできる限り取り除く目的で、検査員 は絶えず掌を乾布で拭いてから検査試料に触れることとした。

表 2 に、官能検查の分散分析結果を示す。表より、いずれの動作、 姿勢と試料面の向きとの組合せでも主効果の分散比が高度に有意と なっていることから、接触抵抗に起因する動作支援、姿勢保持のし やすさに対する検査員の判断には共通の基準があること、および本 検査自体が有効であることが確認できる。また、椅子座り・水平、 椅子座り · 鉛直、歩行 - 水平、歩行 - 鉛直の場合を除き個人差も有 意となっているが、寄与率が小さいため大きな問題とはならず、構 成する尺度が有効であることが確認できる。

表 2 分散分析結果

\begin{tabular}{|c|c|c|c|c|c|c|c|c|c|}
\hline & \multicolumn{6}{|c|}{ 動作のしやすさ } & \multirow{2}{*}{\multicolumn{2}{|c|}{$\frac{\text { 姿勢保持のしやすさ }}{\text { 片足立ち }}$}} \\
\hline & & \multicolumn{2}{|c|}{ 椅子立ち } & \multicolumn{2}{|c|}{ 椅子座り } & \multicolumn{2}{|c|}{ 歩行 } & & \\
\hline & & 水平 & 鉛直 & 水平 & 鉛直 & 水平 & 鉛直 & 水平 & 鉛直. \\
\hline \multirow{2}{*}{ 分散比 } & 主効果 & $31.41 *$ & $18.70 *$ & $11.41 *$ & $15.64 *$ & $40.49 *$ & 15. $39 *$ & 47. $43 *$ & $41.21 *$ \\
\hline & 個人差 & $2.61 *$ & 2. $50 *$ & 2.08 & 1.44 & 2. 06 & 0.91 & 2. $62 *$ & $2.61 *$ \\
\hline \multirow{2}{*}{ 寄与率 } & 主効果 & 0.63 & 0.48 & 0.36 & 0.46 & 0.68 & 0.47 & 0.70 & 0.67 \\
\hline & 個人差 & 0.04 & 0.09 & 0.08 & 0.03 & 0.04 & -0.01 & 0.05 & 0.06 \\
\hline
\end{tabular}


以上から、検査で得られた基礎データを用いて、尺度構成理論 ${ }^{6)}$ に従い、6 種の支援尺度および 2 種の保持尺度を構成した。

\section{3 心理学的尺度相互の関係の検討}

5.2 で構成した尺度相互の関係の例を、図 1 に示す。図の(イ) は動作の異なる尺度相互の関倸の例、(口) は支援尺度と保持尺度の 関係の例、(ハ)は試料面の向きの異なる尺度相互の関係の例を示し たものである。
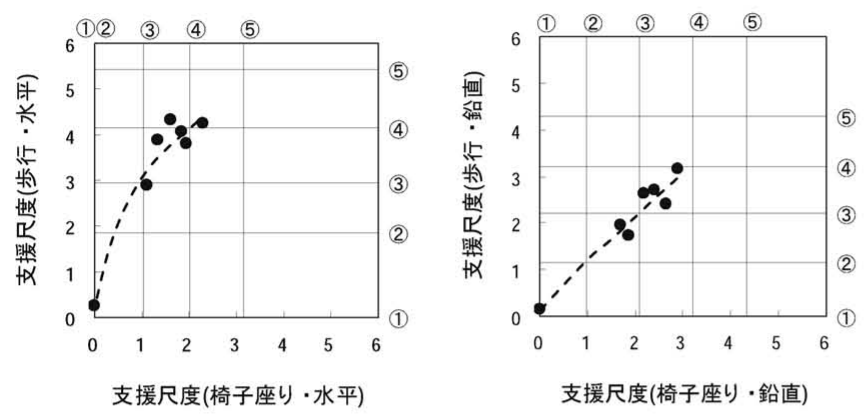

（イ）動作の異なる尺度相互の関係の例
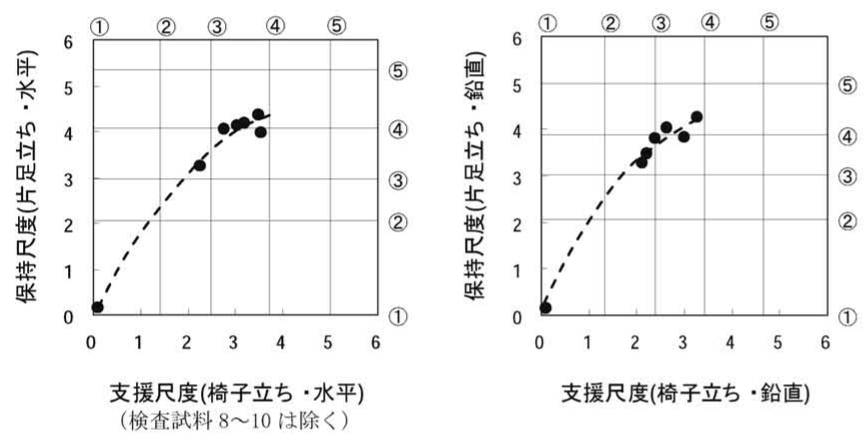

（口）支援尺度と保持尺度の関係の例
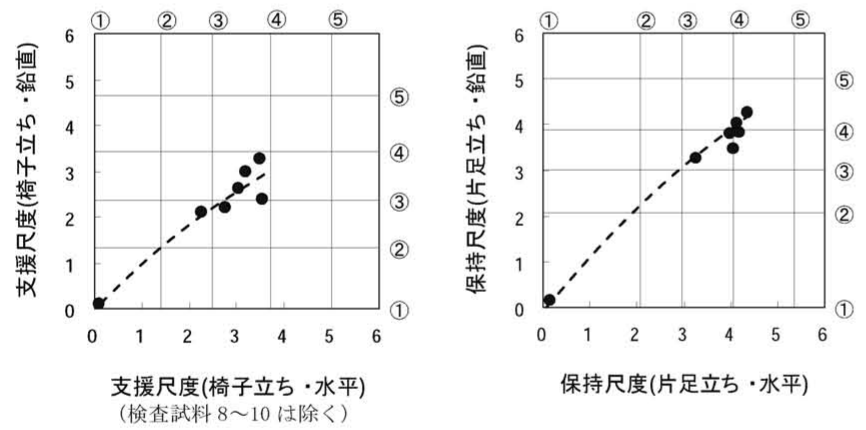

（ハ）試料面の向きが異なる尺度相互の関係の例

(1)〜 (5): 判断範ちゅう (表 1 参照)

図1 掌での心理学的尺度相互の関係の例

図より、いずれの尺度の組合せでも、多少の乱れが見受けられる 場合もあるが、おおむ福良い対応が得られていることがわかる。ま た、図示しなかった組合せでも、同様の傾向がみられた。すなわち、 掌での接触抵抗からみた検查試料の相対的序列は、動作、姿勢、試 料面の向きにより大きくは変化しないとみなせることが明らかとな った。さらに、この結果から、本検査で選定しなかった動作、姿勢、 試料面の向きでも、掌での接触抵抗からみた検查試料の相対的序列 は大きくは変化しないことが推定できる。
以上より、本検査で設定した条件の範囲では、1つの動作、姿勢、 試料面の向きを対象に、掌での接触抵抗からみた検查試料の相対的 序列と良い対応を示寸接触抵抗の測定方法を究明できれば、他のす べての動作、姿勢、試料面の向きでの接触抵抗の測定にも適用でき、 かつ測定される接触抵抗を用いて動作支援、姿勢保持の観点から部 位・部材を評価できる可能性が高いとみなすことができる。

\section{6. 掌での接触抵抗試験機の設計・試作および心理学的尺度と接触 抵抗の関係の検討}

\section{1 試験機の基本構想}

既報では、指での接触抵抗を測定する妥当な試験機を設計・試作 した。図2、写真 2 に、その概要を示す。本試験機は、接触抵抗片、 接触抵抗片固定台、重鍾、荷重計などからなり、評価対象の部位・ 部材を水平に設置し、その上に試験機を乗せ、接触抵抗片に重錘の 質量を載荷した状態で試験機全体を所定の方向に引張り、試験機が 動き出した時に荷重計で測定される荷重を接触抵抗值として求める ものである。
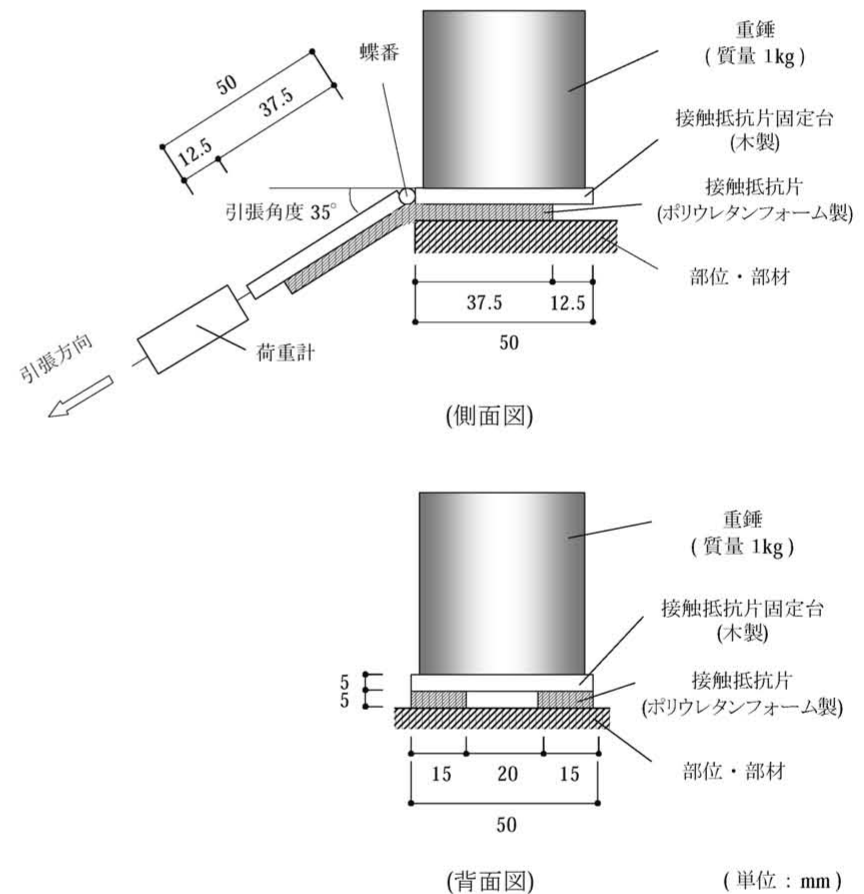

図 2 指での接触抵抗試験機の概要 ${ }^{1)}$

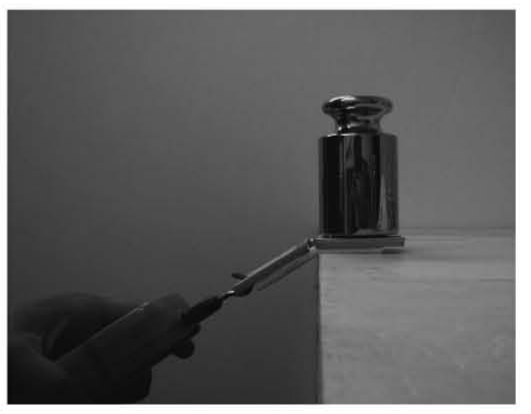

写真 2 指での接触抵抗試験機 
本試験機の接触抵抗片の平面形状、面積は、指 2 本が部位・部材 に触れた時の接触部分の形状、面積を置換したものである。これは、 既報で、指での接触抵抗からみた部位・部材の相対的序列は触れて いる指の本数、指の触れ方により大きくは変化しないことが明らか となったことによる。また、蝶番を利用して接触抵抗片固定台が中 央で折れ曲がるようになっているが、これは、種々の指の触れ方の うち、部位・部材の角部に第一関節までがかかった状況を再現した ものである。さらに、重錘の質量は、指が触れた時に部位・部材に 加わる接触面と直交方向の荷重を参考に設定している。

ここで、部位・部材の角部に指で触れる場合も対象とした既報と、 平らな面に掌で触れる場合を対象とした本報では、接触抵抗片の平 面形状、面積や試験機を引張る方向を変更する必要があることは明 らかであるが、基本的な動作、姿勢は大きくは異ならないことから、 本報では、既報で設計・試作した試験機と同様の機構で接触抵抗片 の平面形状、面積や引張方向を変更した試験機の適用を試みること とした。

図 3 に、掌での接触抵抗試験機の基本構想を示す。本試験機も、 接触抵抗片、接触抵抗片固定台、重鍾、荷重計からなるが、接触抵 抗片の平面形状は、指を置換したものから、掌を置換したものに変 更している(詳細は、6.2で述べる)。また、試験機を引張る方向は、 平らな面を対象としていることから、水平方向のみとしている。

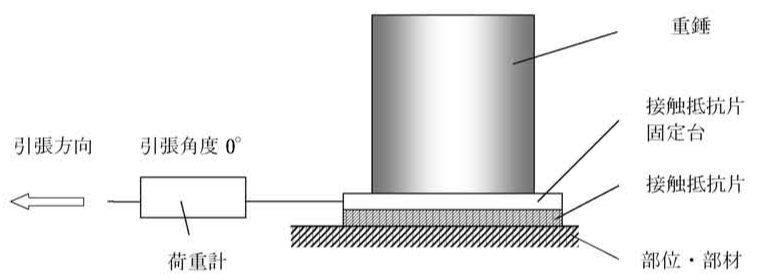

図 3 掌での接触抵抗試験機の基本構想

\section{2 試験機の設計·試作および心理学的尺度と接触抵抗值の関係 の検討}

6. 1 で述べた基本構想に従って、掌での接触抵抗試験機を設計・ 試作したうえで、その仕様について検討した。

まず、部位・部材と接触する部分である接触抵抗片については、 既報で用いたポリウレタンフォーム (見かけ密度 : $30 \mathrm{~kg} / \mathrm{m}^{3}, 25 \%$ 圧 縮硬さ： $3 \mathrm{kPa}$ ，厚さ： $5 \mathrm{~mm}$ )の適用を試みることとした。

次に、接触抵抗片の面積を検討するため、掌が部位・部材に触れ た時の接触部分の面積を測定した。その結果、個人差が大きいもの の、接触部分の幅は 50〜 $80 \mathrm{~mm}$ 程度、面積は $25 \sim 64 \mathrm{~cm}^{2}$ の範囲に分 布しており、なかでも $25 \sim 40 \mathrm{~cm}^{2}$ 程度の值が多くみられた。このた め、接触抵抗片の幅を $50 \mathrm{~mm}$ としたうえで、面積を $25 \mathrm{~cm}^{2} 、 30 \mathrm{~cm}^{2}$ 、 $40 \mathrm{~cm}^{2}$ の 3 種設定し、検討を行うこととした。

また、重錘の質量を検討するため、掌が触れた時に部位・部材に 加わる接触面と直交方向の荷重を測定した。その結果、動作、姿勢 や試料面の向きによる差や個人差が大きいものの、荷重は 0.5 9. $4 \mathrm{kgf}$ の範囲に分布しており、なかでも $0.5 \sim 2 \mathrm{kgf}$ 程度の值が多く みられた。このため、重錘の質量を $0.5 \mathrm{~kg} 、 1 \mathrm{~kg} 、 2 \mathrm{~kg}$ の 3 種設定し、 検討を行うこととした。

以上のように設定した接触抵抗片の面積 3 種 $\times$ 重鍾の質量 3 種 $=9$
種の仕様で、検查試料の接触抵抗值を測定した。具体的には、接触 抵抗片固定台に木片と鋼製フックを介して連結された荷重計をおよ そ $150 \mathrm{~mm} / \mathrm{s}$ の速さで引き、試験機が動き出した時に荷重計が示寸最 大值を記録した。測定は、検查試料ごとに 10 回ずつ行い、結果に極 端なばらつきはみられず安定していることを確認したうえで、平均 を求めた。この平均值と、 5.2 で構成した心理学的尺度の関係を検 討した。

図 4 に、結果の一例として、支援尺度 (椅子立ち・水平) と接触抵 抗值の関係を示す。図に示すように、いずれの仕様で測定した接触 抵抗值も支援尺度とおおむ称良い対応を示しており、図に点線で示 寸対応の中心傾向を表す曲線を目視で描くことができることから、 接触抵抗片の材質や、接触抵抗片の平面形状、面積および重鍾の質 量の範囲に、大きな問題はないことがわかる。また、9 種の仕様の なかでは、接触抵抗片の面積 $30 \mathrm{~cm}^{2}$ ・重鍾の質量 $1 \mathrm{~kg}$ の組合せでの 接触抵抗值が、心理学的尺度との対応がより良いとみなすことがで きる。この傾向は、他の支援尺度および保持尺度でも同様であった。
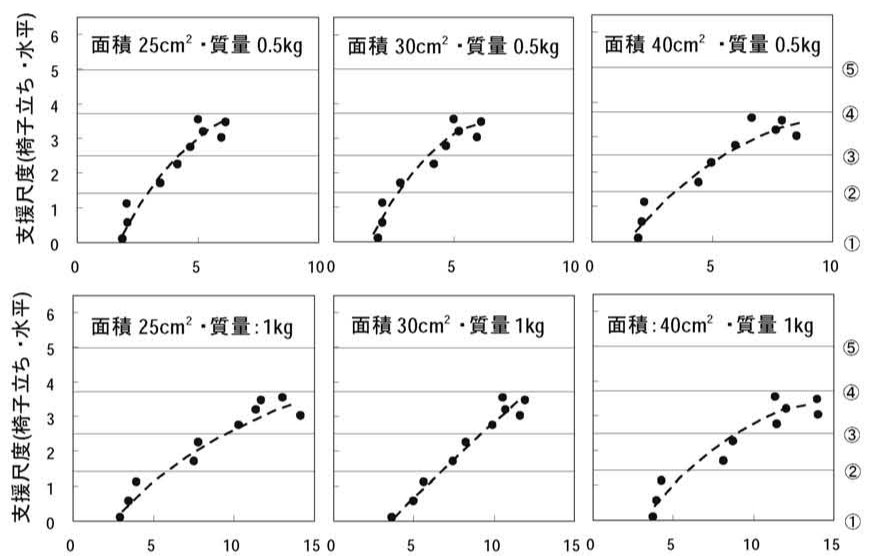

接触抵抗値 $(\mathrm{N})$

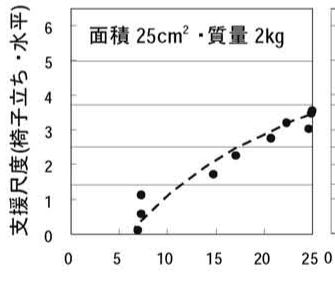

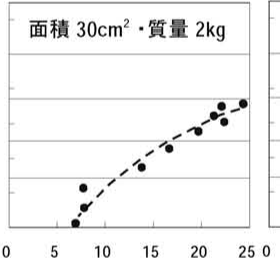

接触抵抗値 $(\mathrm{N})$

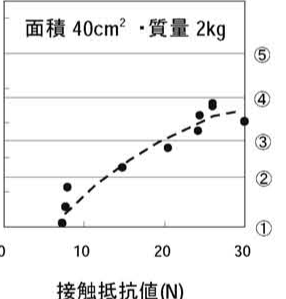

接触抵抗值 $(\mathrm{N})$
(1)〜 (5): 判断範ちゅう (表 1 参照)

図 4 掌での支援尺度 (椅子立ち・水平) と接触抵抗值の関係

図 5 に、接触抵抗片の面積 $30 \mathrm{~cm}^{2}$ ・重鍾の質量 $1 \mathrm{~kg}$ の組合せで測 定した接触抵抗值と、 5.2 で構成したすべての支援尺度、保持尺度 の関係を示す。図より、いずれの動作、姿勢、試料面の向きでも両 者はよい対応を示していることがわかる。

以上より、掌での接触抵抗試験機の仕様として、接触抵抗片の材 質をポリウレタンフォーム (見かけ密度 : $30 \mathrm{~kg} / \mathrm{m}^{3}, 25 \%$ 圧縮硬さ： $3 \mathrm{kPa}$ 、厚さ: $5 \mathrm{~mm}$ )、接触抵抗片の面積を $30 \mathrm{~cm}^{2}$ (幅 $50 \times$ 長さ $60 \mathrm{~mm}$ )、 重鍾の質量を $1 \mathrm{~kg}$ と設定した。掌での接触抵抗試験機の概要を、図 6、写真 3 に示す。

また、任意の部位・部材の接触抵抗を掌での接触抵抗試験機を用 いて測定し、結果を図 5 と照合することにより、動作支援、姿勢保 持の観点から評価することが可能であることから、本報では図 5 を、 

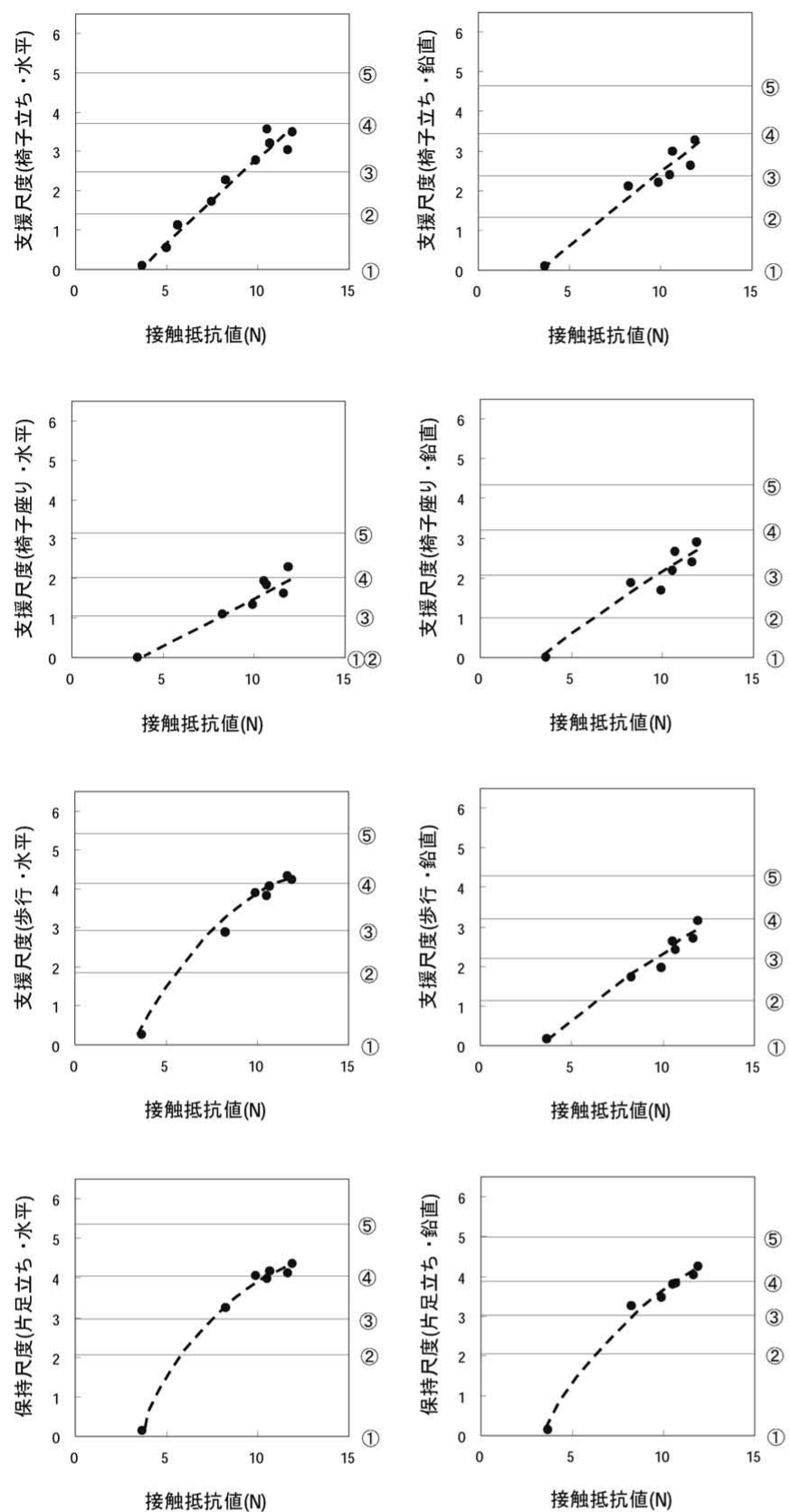

(1)〜 (5): 判断範ちゅう (表 1 参照)

図 5 掌での支援尺度、保持尺度と接触抵抗值の関係

動作支援、姿勢保持からみた掌での接触抵抗の評価指標として提示 する。

\section{7. 手を接触させる場合の心理学的尺度の構成}

\section{1 官能検查の概要、経過、結果および心理学的尺度相互の構成}

心理学的尺度構成のための官能検査を、 5.1 で述べたのと同様の 要領で行った。官能検査の概要は、表 1 と同様である。すなわち、 検查試料に掌のみでなく手で触れること以外は、 5.1 で述べたのと 同一の条件で官能検查を行った。1 人の検查員の検查に要する時間 は、休憩時間を含め約 1 時間であった。

表 3 に、官能検查の分散分析結果を示す。表より、 5.2 で述べた のと同様の理由で、接触抵抗に起因寸る動作支援、姿勢保持のしや

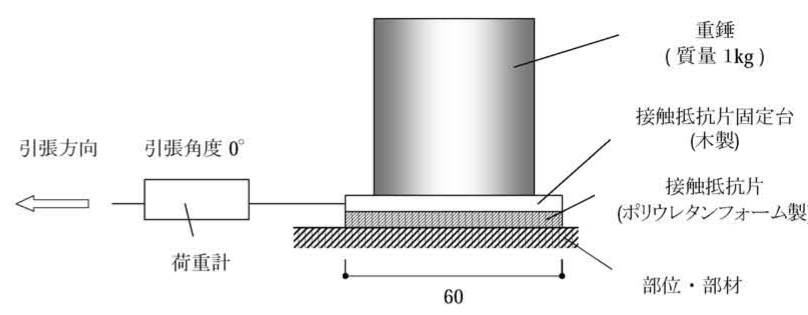

(側面図)

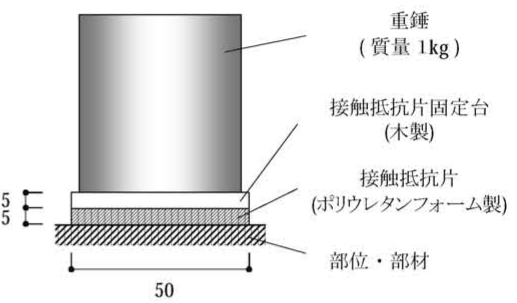

(背面図) (単位：mm)

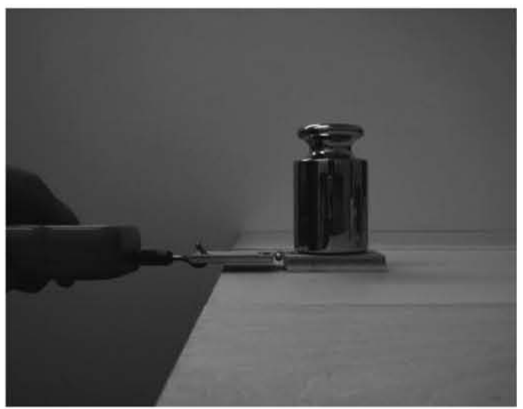

写真 3 掌での接触抵抗試験機

すさに対する検査員の判断には共通の基準があること、および本検 查自体が有効であることが確認できる。また、椅子立ち・水平、歩 行・水平の場合を除き個人差も有意となっているが、寄与率が小さ いため大きな問題とはならず、構成する尺度が有効であることが確 認できる。

以上から、検査で得られた基礎データを用いて、尺度構成理論 5) に従い、6 種の支援尺度および 2 種の保持尺度を構成した。

表 3 分散分析結果

\begin{tabular}{|c|c|c|c|c|c|c|c|c|c|}
\hline & \multicolumn{6}{|c|}{ 動作のしやすさ } & \multirow{2}{*}{\multicolumn{2}{|c|}{$\frac{\text { 姿勢保持のしやすさ }}{\text { 片足立ち }}$}} \\
\hline & & \multicolumn{2}{|c|}{ 椅子立ち } & \multicolumn{2}{|c|}{ 椅子座り } & \multicolumn{2}{|c|}{ 歩行 } & & \\
\hline & & 水平 & 鉛直 & 水平 & 鉛直 & 水平 & 鉛直 & 水平 & 鉛直 \\
\hline \multirow{2}{*}{ 分散比 } & 主効果 & 18. $44 *$ & $18.31 \%$ & $27.58 *$ & 19. $78 *$ & $23.59 *$ & 46. $39 *$ & $51.11 *$ & 59. $26 *$ \\
\hline & 個人差 & 1.80 & 2. $94 *$ & 2. $84 *$ & 2. $55 *$ & 1.88 & 3. $10 *$ & $5.20 *$ & 4. $13 *$ \\
\hline \multirow{2}{*}{ 寄与率 } & 主効果 & 0.51 & 0.46 & 0.57 & 0.49 & 0.56 & 0.69 & 0.66 & 0.72 \\
\hline & 個人差 & 0.03 & 0.11 & 0.09 & 0.09 & 0.05 & 0.07 & 0.12 & 0.08 \\
\hline
\end{tabular}

\section{2 心理学的尺度相互の関係の検討}

7.1 で構成した尺度相互の関係の例を、図 7 に示す。

図より、5.3で述べたのと同様、いずれの尺度の組合せでもおお 
むね良い対応が得られていることがわかる。すなわち、掌で触れる 場合と同様に、本検查で設定した条件の範囲では、1つの動作、姿 勢、試料面の向きを対象に、手での接触抵抗からみた検查試料の相 対的序列と良い対応を示寸接触抵抗の測定方法を究明できれば、他 のすべての動作、姿勢、試料面の向きでの接触抵抗の測定にも適用 でき、かつ測定される接触抵抗を用いて動作支援、姿勢保持の観点 から部位・部材を評価できる可能性が高いとみなすことができる。
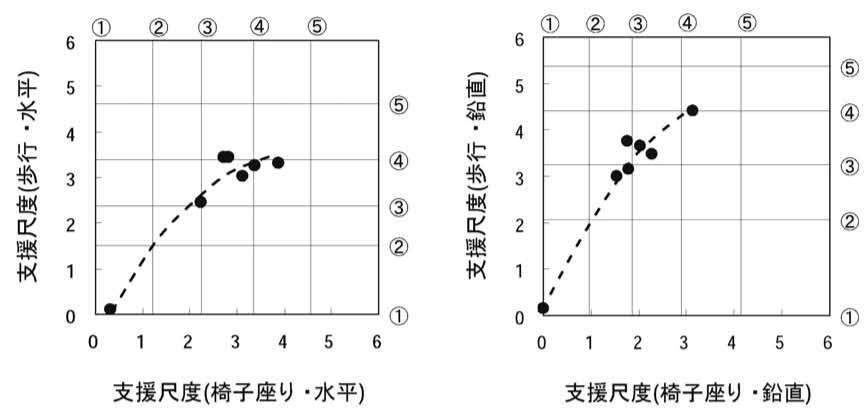

(イ）動作の異なる尺度相互の関係の例
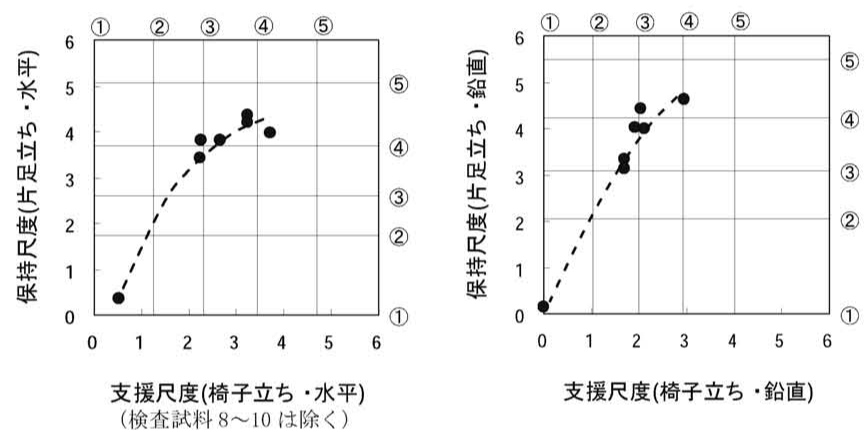

(口) 支援尺度と保持尺度の関係の例
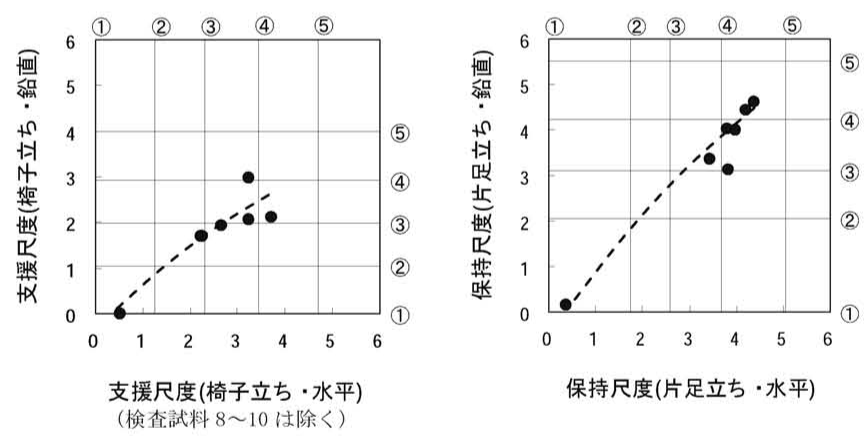

（ハ）試料面の向きが異なる尺度相互の関係の例

(1)〜 (5): 判断範ちゅう(表 1 参照)

図 7 手での心理学的尺度相互の関係の例

\section{8. 手での接触抵抗試験機の設計・試作および心理学的尺度と接触 抵抗の関係の検討}

\section{1 試験機の基本構想}

手での接触抵抗を測定する試験機を設計・試作するにあたり、基 本的には、既報で設計・試作した指での接触抵抗試験機と、6.2で 設計・試作した掌での接触抵抗試験機を組合せた試験機の設計・試 作を試みることとした。

\section{2 試験機の設計・試作}

8.1 で述べた基本構想に従って、指での接触抵抗試験機と掌での 接触抵抗試験機を蝶番を用いて連結した試験機を設計・試作した。 図 8、写真 4 に、試験機の概要を示す。ここで、試験機を引張る方 向は、平らな面を対象としていることから、水平方向とした。なお、 荷重計の試験機への連結方法および引張速度は、6.2 で述べたのと 同じとした。
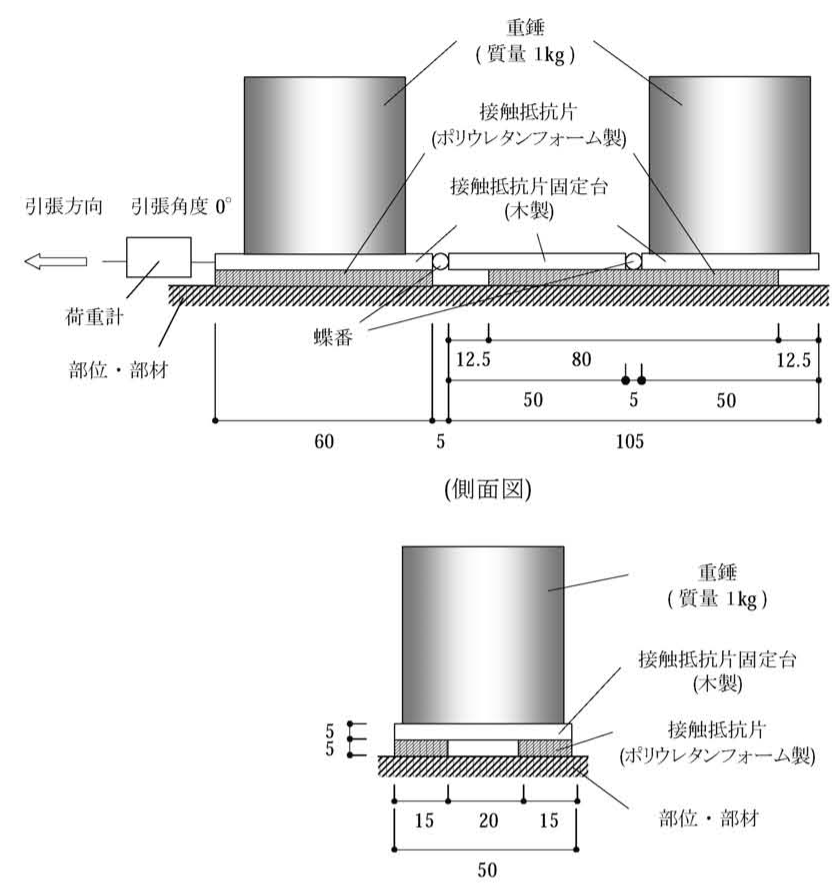

(背面図) (単位 : mm)

図 8 手での接触抵抗試験機の概要

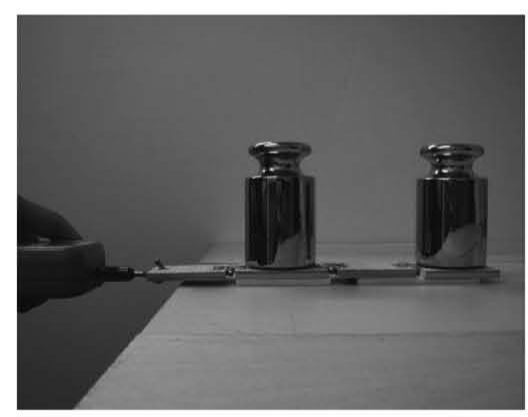

写真 4 手での接触抵抗試験機

\section{3 心理学的尺度と接触抵抗值の関係の検討}

8.2 で設計・試作した試験機で、検查試料の接触抵抗值を測定し た。測定は、検査試料ごとに 10 回ずつ行い、結果に極端なばらつき はみられず安定していることを確認したうえで、平均を求めた。こ の平均值と、7.1 で構成した心理学的尺度の関係を検討した。

図 9 に、支援尺度、保持尺度と接触抵抗值の関係を示寸。図より、 心理学的尺度と接触抵抗值の組合せによっては多少の乱れがみられ るものの、全体的にみて両者はおおむむ放良い詨応を示しており、図 に点線で示す対応の中心傾向を表す曲線を目視で描くことができる。 すなわち、設計・試作した手での接触抵抗試験機の妥当性が確認で 
きる。

また、任意の部位・部材の接触抵抗を手での接触抵抗試験機を用 いて測定し、結果を図 9 と照合することにより、動作支援、姿勢保 持の観点から評価することが可能であることから、本報では図 9 を、 動作支援、姿勢保持からみた手での接触抵抗の評価指標として提示 する。
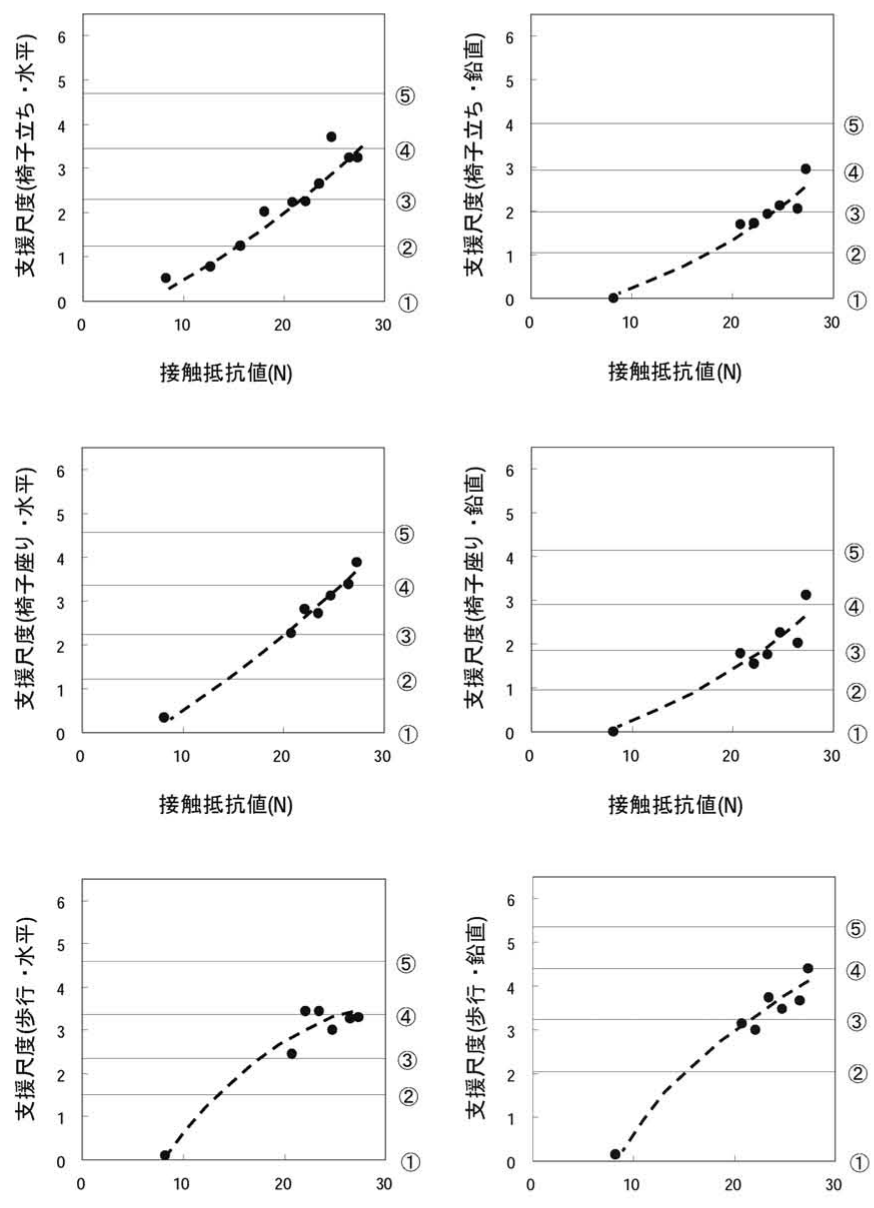

接触抵抗値(N)
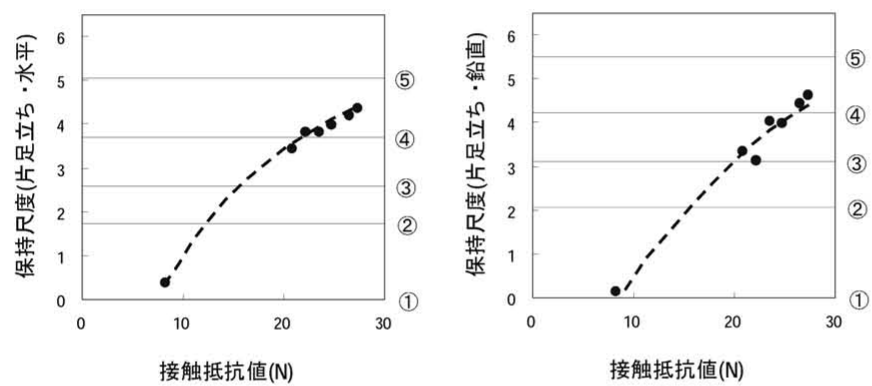

(1)〜 (5): 判断範ちゅう (表 1 参照)

図 9 手での支援尺度、保持尺度と接触抵抗值の関係

\section{9. 掌および手での接触抵抗の評価方法の提示}

動作支援、姿勢保持からみた建築部位・部材の掌および手での接 触抵抗の評価方法を、以下に示す。

(1) 評価対象となる建築部位・部材について、掌での接触抵抗の場合 は図 4、手での接触抵抗の場合は図 8 に示した接触抵抗試験機を
用いて、接触抵抗值を測定する。

(2) (1)で測定した接触抵抗值を、掌での接触抵抗の場合は図 5、手で の接触抵抗の場合は図 9 と照合し、動作支援、姿勢保持の観点か ら接触抵抗を評価する。

以上であるが、通常の部位・部材では、動作支援および姿勢保持 の際、指が触れるか、掌が触れるか、手が触れるか特定できない場 合が多い。このような場合は、既報と本報を活用し、指で触れる場 合、掌で触れる場合、手で触れる場合の評価をそれぞれ求め、この うち最も危険な評価をもって当該部位・部材の接触抵抗の評価とす るべきと考える。

\section{0.結}

動作支援、姿勢保持からみた建築部位・部材の掌での接触抵抗お よび手での接触抵抗の評価方法を提示することを目的とした本報の 結論をまとめると、以下のとおりである。

•既報で設計·試作した指での接触抵抗試験機と同様の機構を有し、 接触抵抗片の平面形状、面積や試験機を引張る方向などを掌が触 れる場合の実状に即して変更した、掌での接触抵抗試験機を設 計・試作し、その妥当性を確認した。

・既報で設計・試作した指での接触抵抗試験機と、本報で設計・試 作した掌での接触抵抗試験機を、実際の手を模擬して連結させた、 手での接触抵抗試験機を設計・試作し、その妥当性を確認した。 ・掌および手での接触抵抗試験機で部位・部材の接触抵抗值を測定 し、心理学的尺度との関係図と照合する方法を、掌および手での 接触抵抗の評価方法として提示した。

以上であるが、本研究で提示した評価指標の高齢者や身体に障害 をもった人々への適用性の厳密な検討は、今後のデータの蓄積など にあわせて順次進めてゆくべき課題と考える。

\section{謝辞}

本研究の必要性および重要性を示唆していただいくとともに、研 究全体のみならず、特に接触抵抗試験機の基本的な考えなど詳細に 到るまで熱心に指導していただいた、小野英哲博士（東京工業大学 名誉教授, 東北工業大学名誉教授, (任) 床性能研究会代表) に、深 く感謝いたします。

\section{参考文献}

1）工藤瑠美, 新美浩二, 細界守明, 古賀 (井戸川) 純子, 横山裕：動作支援, 姿勢保持からみた建築部位・部材の指での接触抵抗の評価方法に関する研 究, 日本建築学会構造系論文集, 第 75 巻, 第 654 号, pp. $1439-1444,2010.8$ 2) 井戸川純子, 小野英哲 : 手摺のすべりの感覚尺度の構成およびすべり試験 機の設計・試作 手のすべりからみた建築部位・部材の安全性の評価方法 に関する研究 (その 1 ), 日本建築学会構造系論文集, 第 513 号, pp. 43 $50,1998.11$

3）井戸川純子, 小野英哲 : 安全性からみた手摺のすべりの相対的評価方法 手のすべりからみた建築部位・部材の安全性の評価方法に関する研究（そ の 2)，日本建築学会構造系論文集，第 523 号，pp. 33 - 38, 1999.9

4）井戸川純子, 小野英哲 : 安全性からみた手と床・壁のす心゙りの相対的評価 方法 手の寸べりからみた建築部位・部材の安全性の評価方法に関寸る研 究 (その 3 ), 日本建築学会構造系論文集, 第 526 号, pp. $25-30,1999.12$

5）小野英哲，高橋宏樹，泉譲太，高橋成明：高齢者の安全性からみた床およ び斜路のすべりの評価方法, 日本建築学会構造系論文集, 第 484 号, pp. 21 - $29,1996.6$

6) J.P.Guilford,秋重義治訳：「精神測定法」培風館

（2010年 9 月 10 日原稿受理，2010年10月15日採用決定） 